\title{
REVISTA DE ARQULELOGIA
}

Volume 31 No. 12018

\section{9: 0 BRASIL ANTES DE CABRAL}

\section{João Carlos Moreno de Sousa ${ }^{1}$}

Reinaldo José Lopes é jornalista científico, escreve para a Folha de São Paulo e é autor do blog 'Darwin e Deus'. A publicação de matérias de temas arqueológicos é muito frequente, e tornam o autor um dos maiores divulgadores do conhecimento arqueológico para o grande público a nível nacional, e '1499: O Brasil Antes de Cabral' é uma prova disso.

O livro se propõe a realizar um apanhado geral da história pré-colonial do território atualmente conhecido como Brasil. O autor, no entanto, pouco escreve sobre as ocupações mais antigas que 14 mil anos atrás ou sobre o povoamento inicial da Américas, provavelmente para evitar ir de frente ao consenso da arqueologia norteamericana, começando a retratar a (pré-) história do Brasil a partir de 13.500 anos antes do presente. É importante notar que as idades mencionadas no livro são idades calibradas e podem dar a impressão de serem equivocadamente mais antigas do que costumamos ver em outras obras não acadêmicas, quando na verdade foram representadas de uma forma mais acurada.

Figura 1 - LOPES, Reinaldo José. 2017. 1499: O Brasil Antes de Cabral. Harper Collins, Rio de Janeiro. 248 p. ISBN: 978-85-9508-032-4.

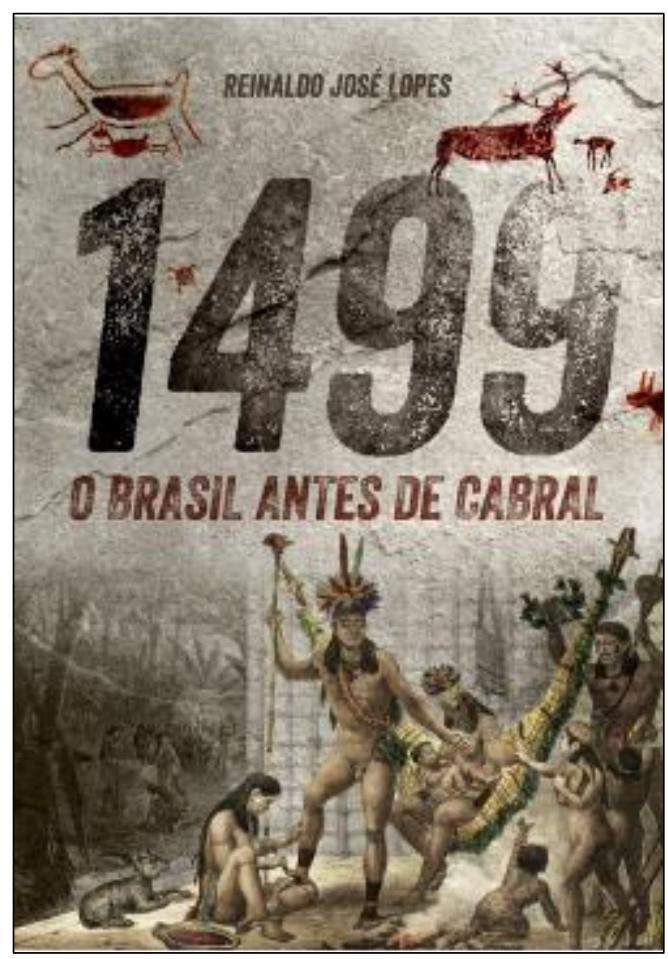

\footnotetext{
${ }^{1}$ PPGArq, Museu Nacional, Universidade Federal do Rio de Janeiro.
} 
A introdução do da obra realça o fato de que o entendimento que possuímos atualmente sobre o passado da humanidade é nitidamente diferente e muito mais detalhado do que tínhamos há poucos anos atrás e explicita a importância que os estudos sobre o passado humano têm nas sociedades atuais. Os próximos seis capítulos do livro são focados em realizar um apanhado cronológico dos grupos de primeiros habitantes do território brasileiro.

O primeiro capítulo trata sobre os grupos caçadores-coletores da transição Pleistoceno-Holoceno e Holoceno Inicial. Por um lado, o Lopes retrata muito bem aspectos biológicos destas antigas populações. Por outro lado, ignora os aspectos culturais. As únicas (e raras) menções às mais antigas indústrias líticas e representações rupestres brasileiras são todas relacionadas à microrregião de Lagoa Santa, em Minas Gerais, deixando de lado a associações de diferentes conjuntos de cultura material a diferentes grupos humanos.

Já o segundo capítulo é totalmente voltado aos grupos litorâneos, especialmente os Sambaquis. Mais uma vez, o autor se preocupa em retratar a biologia e a idade destes grupos humanos, mas ignora quase que totalmente os aspectos culturais e materiais destas sociedades. Não são retratadas as indústrias de artefatos de pedra e osso, é mencionada apenas brevemente a construção dos sambaquis, os zoólitos e os aspectos simbólicos dos sepultamentos.

Posteriormente, o terceiro capítulo retrata o início do manejo e domesticação das plantas, com foco na Amazônia. O autor descreve bem as principais hipóteses sobre os processos que iniciaram a domesticação das plantas, mas volta a ignorar a cultura material que acompanha esse novo modo de vida nas populações pré-cabralinas.

O quarto e o quinto capítulo também são voltados à "queridinha" da pré-história brasileira: a Amazônia. Ambos os capítulos, mais uma vez, retratam muito bem as discussões teóricas de complexidade social, política e econômica sobre as populações que ali viviam durante o Holoceno Tardio, e desta vez menciona alguns importantes aspectos de cultura material, como as estruturas de montículos e geoglifos, e a cerâmica tupi-guarani e marajoara.

Ainda, Reinaldo José Lopes, no sexto capítulo, trata de descrever a dispersão dos grupos ameríndios em território brasileiro, baseando-se nas famílias linguísticas destes mesmos grupos. Mais uma vez, o autor se prende na Amazônia, tendo como exceção uma menção aos estudos de grupos Jê em Santa Catarina.

Por fim, Lopes encerra o livro com um epílogo, em que discute como a chegada dos colonizadores (invasores) europeus causou diversos problemas para a sobrevivência das populações que vieram a ser referidas como indígenas, e como a relação entre as sociedades indígenas e a sociedade "moderna" poderia ter sido diferente desde o começo.

A obra não é voltada ao público acadêmico, mas a um público muito mais abrangente. $\mathrm{O}$ autor escreve de forma pela qual a leitura flui facilmente, evitando o uso de termos técnicos os quais apenas arqueólogos e outros cientistas entendem. No entanto quando o faz, o autor busca explicá-los de uma forma simples, porém acurada, para que o leitor os compreenda. Quando o autor entende que o assunto tratado no livro é muito complexo para a maioria dos leitores, ele se dá ao direito de realizar pausas para "explicações técnicas" e elucida estes mesmos assuntos, tais como datação radiocarbônica, análise genética, análise isotópica e estudos de complexidade social. Apesar de não ser um arqueólogo, Lopes, enquanto jornalista científico, toma o cuidado para respeitar e utilizar termos que evitam a propagação de estereótipos pré-históricos. Um exemplo disso é a aplicação correta do termo "humanos anatomicamente modernos", ao invés de Homo sapiens, para se referir aos seres humanos atuais em 
certos momentos.

As principais falhas do autor estão em retratar a pré-história brasileira com um foco quase que limitado aos aspectos biológicos dos primeiros grupos humanos do atual território brasileiro, e no foco quase que limitado à Amazônia ao tratar de grupos menos antigos. Lopes é muito preciso no apanhado que realiza sobre a pré-história, mas esta poderia ser muito mais acurada se ele tivesse descrito os principais conjuntos de materiais (representações rupestres e indústrias de artefatos líticos e cerâmicos) que levaram arqueólogas e arqueólogos a identificar diferenças culturais em todo o território brasileiro. Talvez em uma segunda edição da obra algumas páginas que descrevam resumidamente a diversidade de cultura material pré-histórica brasileira seja possível.

Apesar das falhas em sua obra, Reinaldo José Lopes claramente tem uma noção excelente da importância da arqueologia para as sociedades atuais e é muito feliz em transmitir esta mensagem. O último trecho da obra é a prova disso, sendo uma perfeita resposta à questão da importância dos estudos de arqueologia pré-histórica brasileira: "A pré-história é a chave para entender estas condições iniciais [de contato de indígenas e europeus] e para demonstrar que o passado profundo do Brasil é tão rico e complexo quanto o do Velho Mundo. Em nome dos herdeiros dele, convém não esquecê-lo" (p. 232). Enfim, '1499' é uma obra que definitivamente despertará o interesse de muitas pessoas à pré-história brasileira e convém ser lida por acadêmicos não arqueólogos que buscam ter uma mínima noção no tema.

Palavras-chave: Arqueologia brasileira; pré-história; sociedades indígenas.

Keywords: Brazilian archaeology; prehistory; indigenous societies.

Palabras clave: Arqueología brasileña; prehistoria; sociedades indígenas. 